\section{From Impact to Riches: \\ Evolution of Geological Understanding as Seen at Sudbury, Canada}

\author{
Anthony J. Naldrett, University of Toronto
}

As I thought about a topic for this address, I decided that I should pick something that has been a major factor, perhaps the major factor in my professional life-the world's nickel capital, Sudbury, Ontario. On setting out in July 1957 from Britain to make a life in North America, I was fortunate to obtain a job with Falconbridge Nickel Mines Limited in one of their mines at Sudbury. In my subsequent career as a graduate student, postdoctoral fellow, and academic, I have been lucky enough to stay in close touch with the new developments in Sudbury geology as they have occurred over the intervening 45 years. The developments have been startling and I believe provide an object lesson as to how progress in our particular science commonly occurs. Therefore my intention in this address is not to discuss every aspect of the geology, but to give you a personalized view of the major jumps in our understanding about Sudbury, how they came to be made, and how one led to the other.

First, a little history. The presence of sulfides was initially reported at Sudbury in an 1856 Geological Survey of Canada Report as documented in the following Geological Survey of Canada, 1853-1856, p. 180-181):

Previous to my visit to Whitefish lake, I had been informed by Mr Salter that local attraction of a magnet had been observed by himself while running the meridian line and he expressed it to be his opinion that the presence of a large body of iron ore was the immediate cause. When therefore, I came to the part indicated by Mr Salter, I made a direction of the meridian line but for a considerable distance on each side of it, and the result of my examination was that the local attraction, which I found exactly as described by Mr Salter, was owing to an immense mass of magnetic trap. Specimens of this trap given to $\mathrm{Mr}$ Hunt for analysis and the result of the quotation (Report of Alexander Murray, very careful examination not only in the investigation shows that it contains magnetic iron ore and magnetic iron pyrites generally disseminated throughout the rock, the former in very small grains: titaniferous iron was found associated with the magnetic ore, and a small quantity of nickel and copper with the pyrites.

These remarks were not followed up. It was only after sulfides were revealed in a new railway cutting in 1883 as a result of the building of Canada's first transcontinental railroad, the Canadian Pacific, that a prospecting and staking rush started in the area. The first production at Sudbury occurred in 1886 (Fig. 1). During the late nineteenth and early twentieth centuries, laterites in New Caledonia satisfied the majority of the world's demand for nickel, but by 1905 the sulfide mines at Sudbury had overtaken New Caledonia as the principal source of supply. Thereafter, Sudbury production waxed and waned according to demand. The early companies soon merged into what eventually became INCO Limited, but in 1928 another significant company, Falconbridge Nickel Mines Ltd., appeared on the Sudbury scene and has continued to this day. The slackening in the growth rate that is shown in Figure 1 as having set in during the 1960s, and having continued to this day, coincides with the discovery of the Talnakh deposits of the Noril'sk area, which exceed Sudbury in terms of their grade and resources of $\mathrm{Ni}, \mathrm{Cu}$, and platinum group elements (PGE).

Turning to the geology, the principal aspects are summarized in chronological order in Table 1 and are illustrated in the simplified geological map appearing as Figure 2. An Archean hinterland comprising granites and felsic gneisses (shown in pink in Fig. 2) was affected by $2.46 \mathrm{Ga}$ rifting that gave rise to a southern ocean. The northern margin of the rift is shown in red in Figure 2. The Huronian Supergroup, shown in yellow, comprises greenstones, greywackes, and quartzites that were deposited along the margin of the rift. North of the northern margin, the Huronian rocks form a thin shelf cover on

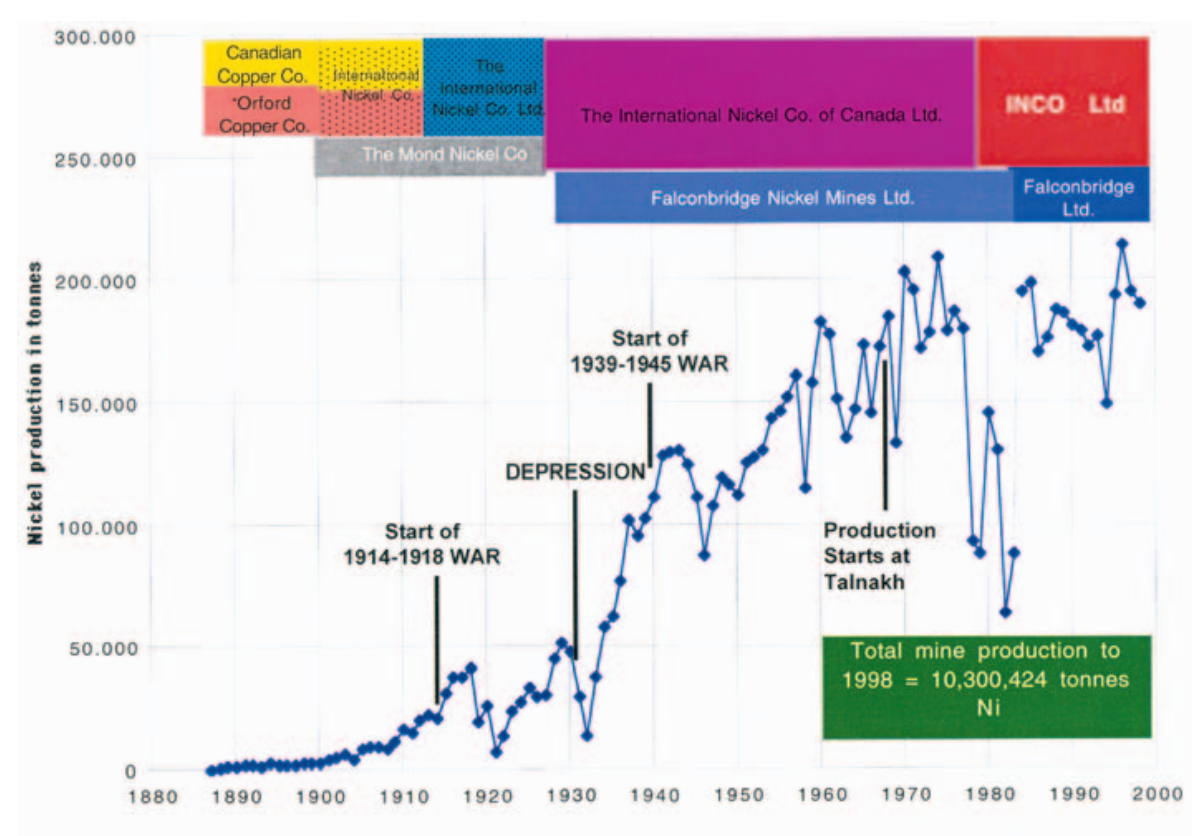

Figure 1. Production of Ni metal in tonnes from 1886 to 1998. The principal mining companies operating at Sudbury are shown at the top of the diagram. 


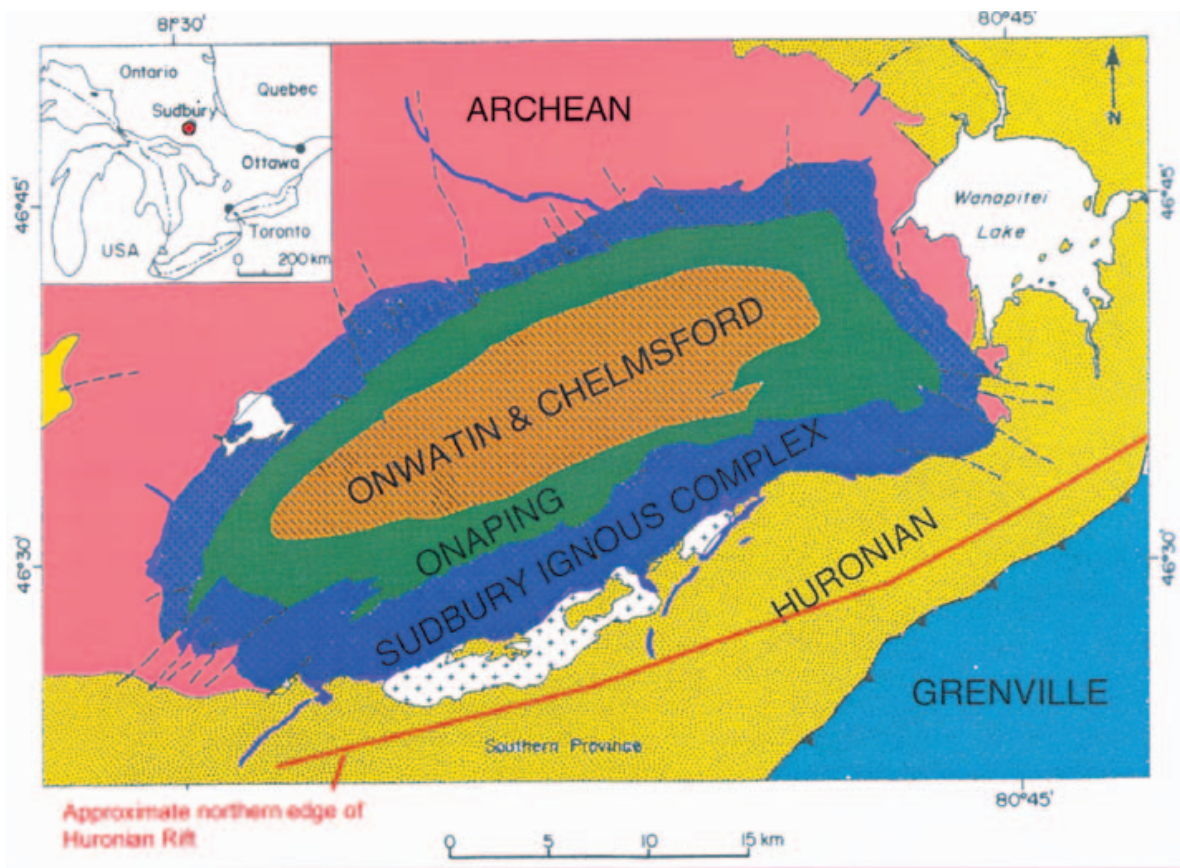

Figure 2. Simplified geological map of the Sudbury area showing the approximate northern edge of the Huronian rift. the Grenville metamorphism and deformation at 1.2-1.0 Ga. The Sudbury structure straddles the boundary between the Archean and the Huronian, and rocks belonging to it are exposed principally in a $60 \times 30 \mathrm{~km}$ elliptical basin.

The Sudbury event has left us with a wide variety of rock types, many of which are indicative of an enormous release of energy in the area (see schematic representation in Fig. 3). They include irregular vein-like bodies in country rocks forming the footwall to the basin that are known as Sudbury Breccia. Sheet-like bodies of smashed up and partially melted country rocks line the bottom of the basin and often form the host for sulfides that appear to have settled out of the overlying Sudbury Igneous Complex. Discontinuous lenses of sulfide-rich noritic rocks containing inclusions of country rocks, including, in some areas, a suite of mafic-ultramafic cumulates ranging from dunite to olivine gabbro, are the Archean hinterland, but they thicken rapidly southward into the rift. A suite of gabbroic sills (not shown in Fig. 2) intruded the Huronian Supergroup and underlying Archean rocks at $2.22 \mathrm{Ga}$. It is possible that these sills, which are referred to as Nipissing Diabase, were feeding flood basalts at surface, but if so, no traces of the basalts remain. Closure of the ocean during the 1.9-1.8 Ga Penokean orogeny folded the Huronian rocks. It was during this orogeny that the Sudbury event occurred at $1.85 \mathrm{Ga}$. Apart from an intervening dike swarm (the Sudbury dikes), the last major geological event to affect the Sudbury region was

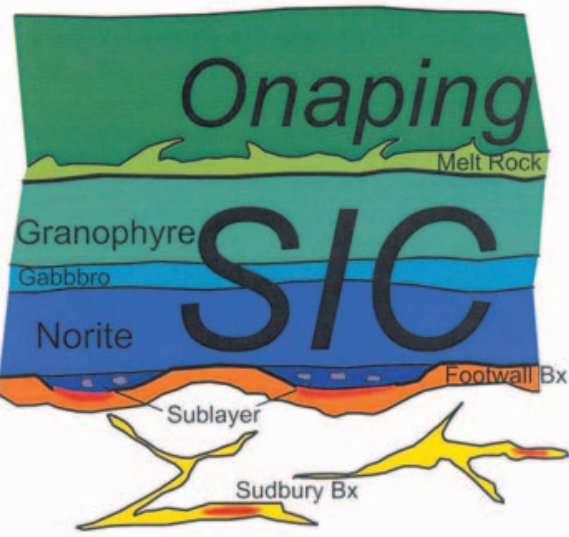

Figure 3. Schematic diagram showing main units resulting from the Sudbury "event." SIC-Sudbury Igneous Complex.

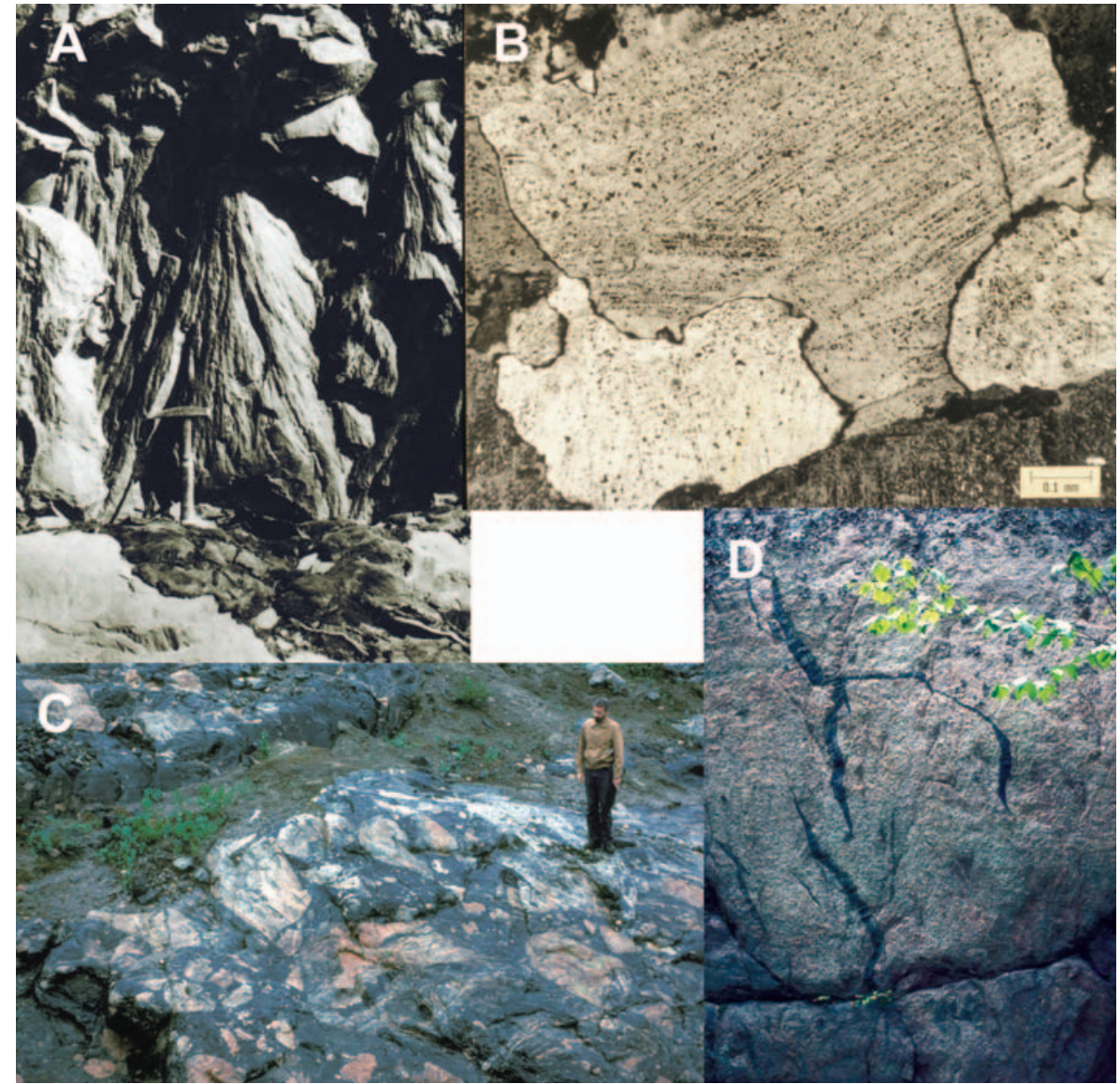

Figure 4. A: A shatter cone from the site south of Kelly Lake, Sudbury, where Bob Dietz first identified them (from Dietz, 1964). B: Shocked quartz showing at least two orientations of original lamellae of thetamorphic glass (photo thanks to Bevan French). C: Large area of Sudbury Breccia (photo thanks to Burkhardt Dressler). D: Thin veinlets of Sudbury Breccia cutting Archean granite (photo thanks to Burkhardt Dressler). 


\begin{tabular}{ll}
\hline \hline Age in Ga & Event \\
\hline$>2.6$ & Formation of Archean greenstones, granite, and felsic gneiss \\
2.46 & Onset of rifting, opening of Southern Ocean Deposition of Huronian Supergroup \\
2.22 & Intrusion of gabbro sills (Nipissing Diabase) \\
$1.9-1.8$ & Penokean Orogeny \\
1.85 & Sudbury event \\
1.25 & Intrusion of Sudbury dikes \\
$1.1-1.0$ & Grenville Orogeny \\
\hline
\end{tabular}

present at intervals along the footwall of the Sudbury Igneous Complex and are referred to as Sublayer. The main body of the complex ranges from quartz-norite at the base through gabbro to granophyre at the top. The uppermost unit associated with the Sudbury event is a series of breccias known as the Onaping Formation.

The principal elements of Sudbury geology were appreciated very early on. A.P. Coleman's 1913 map is remarkably similar to Figure 2. Much of the debate during the first 70 years of mining operations at Sudbury centered on why there was so much granophyre in relation to mafic rock. Some simply accepted Sudbury Igneous Complex as an unusually felsic sill, others explained it as the result of incomplete exposure of a funnelshaped lopolith, and yet others proposed that it was the result of two separate, ring dike-like injections of magma. Nearly all geologists held that the sulfides had settled out of the overlying norite as mag- matic droplets (see summary in Hawley [1962]), although there were a few voices arguing that they were deposited from hot aqueous solutions (Wandke and Hofmann, 1924). Everyone who visited Sudbury was impressed by the enormous energy involved in producing the breccias, and most believed that the source of this energy was volcanic.

With this background, I'm coming to the main focus of my address, which is an account of the major breakthroughs that have come in our understanding of Sudbury, how they came about, and what they led to.

My story begins in May 1962 when Robert Dietz presented himself at the Mine Geology office of Falconbridge Nickel Mines Ltd. near Sudbury, and asked to be taken into the field. Dietz was a U.S. Navy oceanographer who, apart from his other accomplishments in the field of plate tectonics, had developed an interest in shatter cones and their relation-

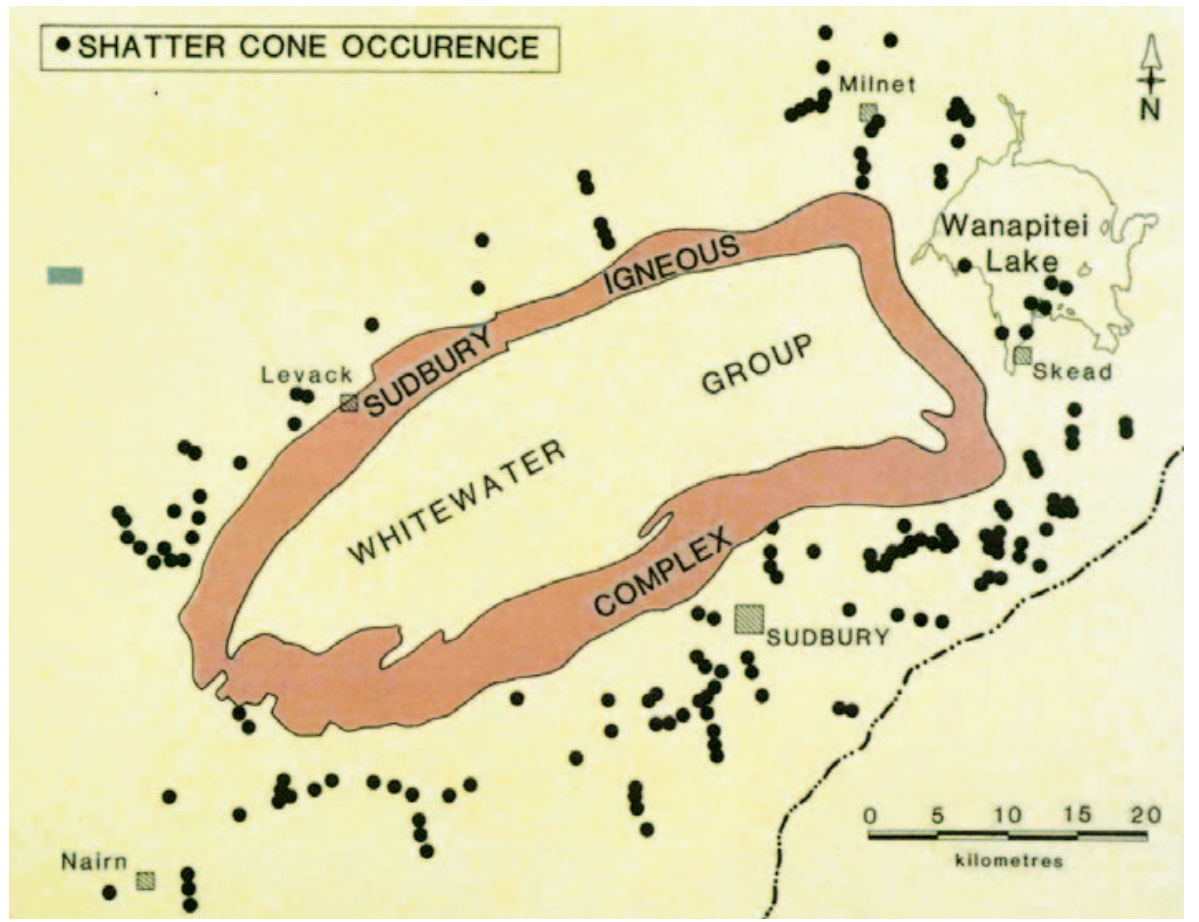

Figure 5. Distribution of shatter cones in the Sudbury area (after Dressler, 1984). ship to meteorite impact craters (Dietz, 1959). Because of this, he was making a systematic study of circular, or nearly circular structures on Earth's surface that were visible via remote imagery. He had been working on the Vredefort dome in South Africa and had convinced himself that this was an impact site. His first line of evidence was shatter cones (Fig. 4A): his argument was that the development of the cones required a shock wave more powerful than that normally developed by terrestrial processes and he came to Sudbury to look for these. Sad to say, he was taken to the wrong place on this first visit, a location inside the Sudbury basin. (As an aside, I should know because I was the junior geologist designated by my superiors to take him into the field.) Fortunately for science, he was not put off by this first failure. He decided that he should be looking outside the structure, not inside, returned the next year, and was successful. The shatter cone in Figure $4 \mathrm{~A}$ is from the locality where he first identified them in quartzites some $7 \mathrm{~km}$ south of the southern margin of the Sudbury Igneous Complex. Dietz wrote up his discovery and conclusions in 1964 (Dietz, 1964), suggesting that Sudbury was an astrobleme and that the nickel present came from an iron meteorite. The first suggestion immediately led to debate, controversy, and a great deal of new research. His second suggestion has been largely discounted over the intervening years. For example, there is as much $\mathrm{Cu}$ at Sudbury as $\mathrm{Ni}$, the relative proportions of siderophile elements are terrestrial, not chondritic, and the osmium isotope systematics indicate a major crustal component. The research stimulated by Dietz's article soon showed that shatter cones are present all around the Sudbury structure (Fig. 5).

The late 1960s were the years when NASA was preparing to visit the moon, and NASA scientists showed a strong interest in developments in Sudbury geology. In the course of their training, the Apollo astronauts came to study analogues of the impact structures that they were likely to find on the moon. One of the NASA scientists who became involved with Sudbury geology at this time was Bevan French. He had been studying deformation in minerals that was the result of shockwaves generated by impact. Amongst other features, shock effects on 
minerals include kink banding in biotite; shock lamellae in quartz and plagioclase; the diaplectic melting of quartz and plagioclase; and the development of the high-pressure $\mathrm{SiO}_{2}$ polymorphs, coesite and stishovite. Experimental data has shown (Horz, 1968; Muller and Defourneaux, 1968) that shockwaves of $100 \mathrm{~kb}$ and more peak pressure produce planar structures in quartz, and that the number of orientations of these structures increases with increasing pressure. In the case of plagioclase, pressures below 100-150 kb do not produce planar features. Between 150 and $300 \mathrm{~kb}$, planar features and isotropisation occur, and between 300 and $500 \mathrm{~kb}$, whole plagioclase crystals become converted to diaplectic glass (von Engelhardt et al., 1967). French reported the discovery of shock features at Sudbury (Fig. 4B) and noted that they strongly supported Dietz's hypothesis (French, 1967). Work conducted in the 1970s and 1980s has shown that shocked quartz extends up to $7 \mathrm{~km}$ from the outer contact along the northern rim of the Sudbury Igneous Complex.

Soon after Dietz's 1964 paper, attention was drawn to the similarity between the Sudbury breccia present outside the Sudbury structure (Figs. 4C and 4D) and pseudotachylites present at the Vredefort ring, which is interpreted as a large impact structure in South Africa (Wilshire, 1971). These breccias, which consist of local country rock fragments in all stages of comminution from 2 to $5 \mathrm{~m}$ diameter on downward, in a fine grained flour apparently also derived locally, are another consequence of the passage of a shockwave. The development of Sudbury Breccia closely mimics the outline of the Sudbury Igneous Complex (Fig. 6).

Concurrent with studies at Sudbury, German scientists were unraveling the geology of the rocks present at the well-documented Riess impact structure near Nordlingen, Bavaria (von Engelhardt et al., 1969). Similarities between impact breccias exposed in outcrop and drill core there and units at Sudbury, particularly the Onaping Formation, became apparent. French (1970), and Peredery (1972) interpreted different members of the Onaping as a series of breccias caused by impact. Avermann (1999) has presented the lat- est synthesis of the Onaping Formation in the light of the impact hypothesis (Fig. 7). In this synthesis, the units range from a basal breccia and impact melt rock up through a ground surge breccia and then suevite to one that is interpreted as due to the collapse of a plume fireball. Breccias around the

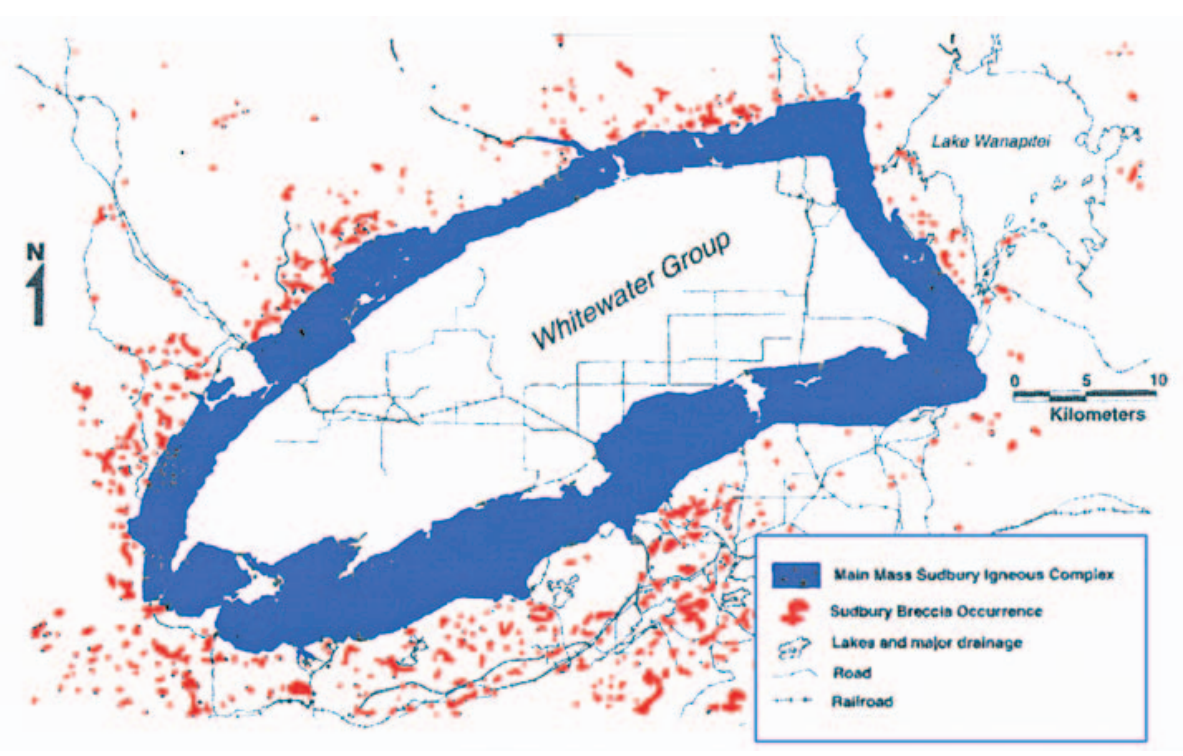

Figure 6. Distribution of Sudbury Breccia in the Sudbury area (after Fedorowich et al., 1999).

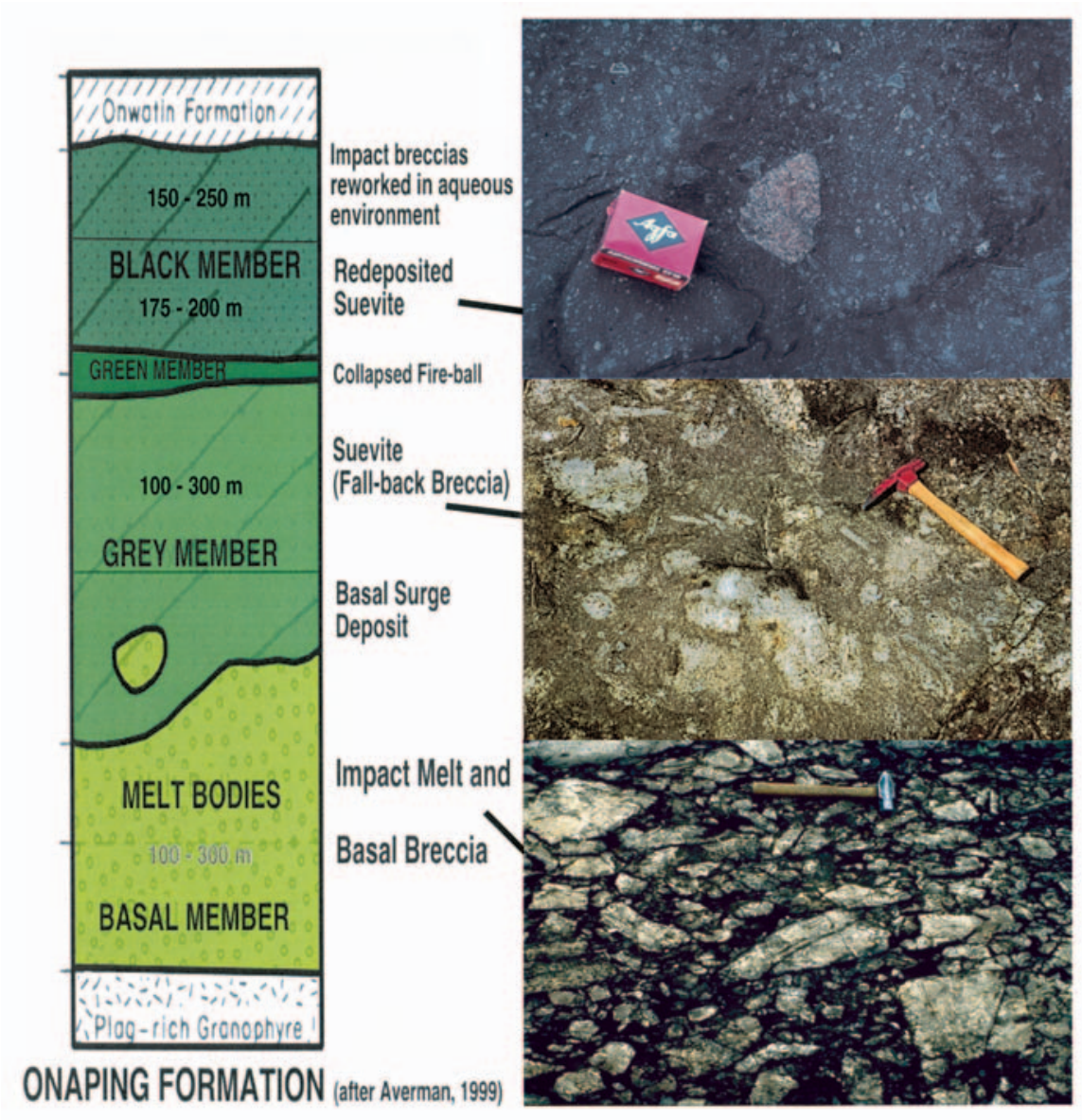

Figure 7. Avermann's (1999) synthesis of the Onaping Formation. Upper photo from Bevan French, middle and lower photos from Burkhardt Dressler. 


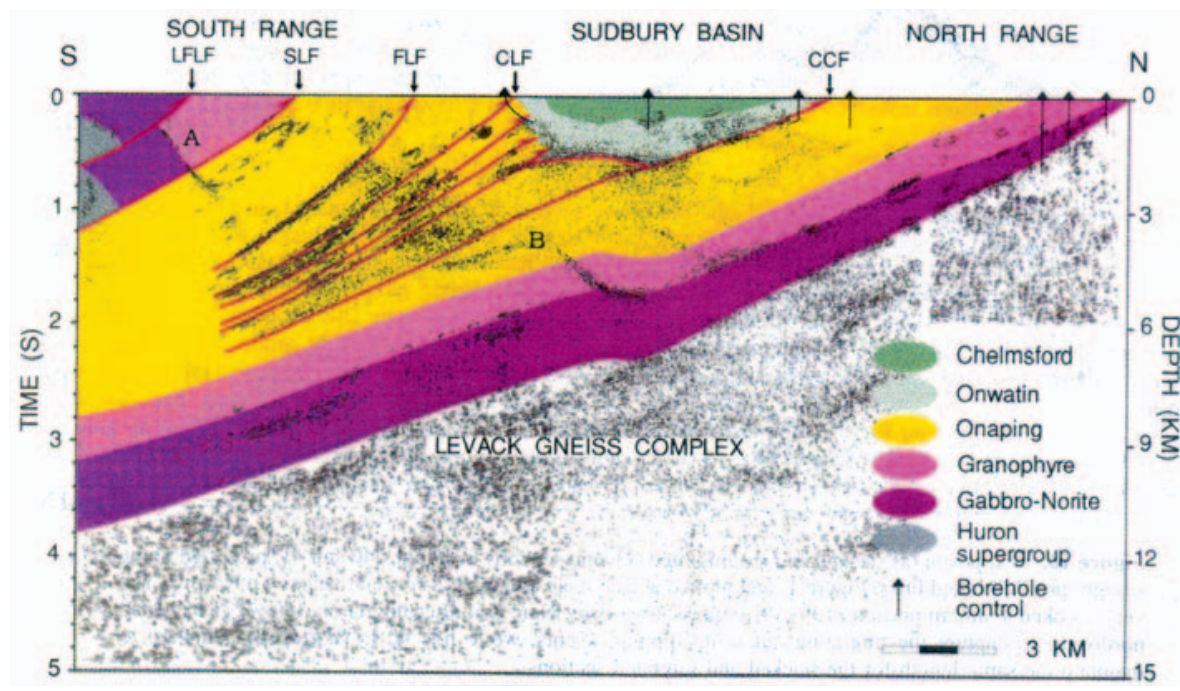

Figure 8. Interpretation of vibroseis data for the Sudbury structure modified after Milkereit et al. (1994).

structure have been reworked and swept into the center of the crater and now form the carbon-rich Black Onaping member, which is the uppermost unit. All of these units contain highly shocked inclusions of country rocks.

The latest evidence for ultrahigh pressure during the Sudbury event is the report by Masaiitis et al. (1999) of micro-diamonds in the Black Onaping.

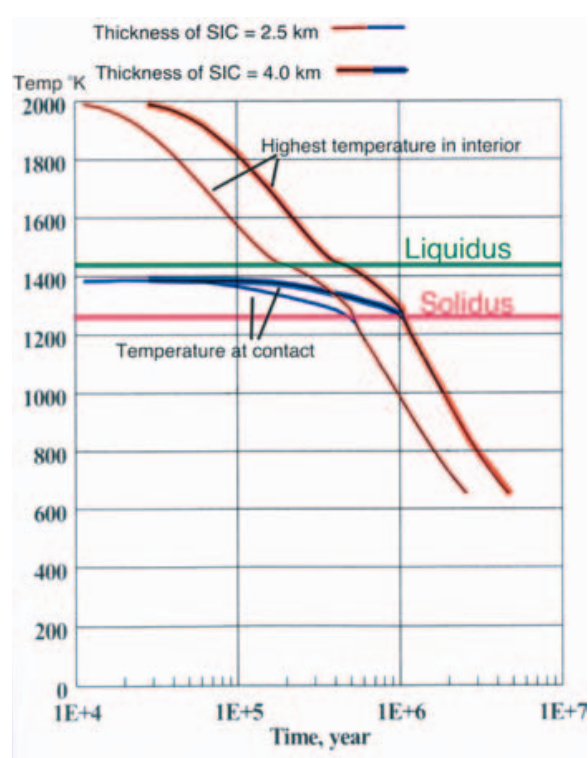

Figure 9. Cooling with time for an impact melt sheets with thicknesses of $2.5 \mathrm{~km}$ (thin lines) and $4 \mathrm{~km}$ (thick lines). Temperatures at the contact are shown in blue and at the hottest point in the interior in red. Modified after Ivanov and Deutsch (1999). SICSudbury Igneous Complex.
These are the most ancient of all impact diamonds discovered so far.

The next definitive advance in understanding arose as a result of Canada's LITHOPROBE program. This comprised a series of seismic transects around the nation analogous to the Co-Corps program conducted in the United States. Sudbury was proposed and selected for a vibroseis survey, and the first transects were conducted in 1990. Part of the motivation had been to determine whether the basal contact of the Sudbury Igneous Complex, along with its rich deposits, was close to the surface beneath the center of the structure. This would have been expected if Sudbury had been affected by the central uplift that characterizes most large impact craters. As seen in Milkereit et al.'s 1994 interpretation (Fig. 8), far from showing a central uplift, the vibroseis data indicate that the northern perimeter of the structure dips smoothly south to beyond the present perimeter of the southern limb. The southern limb has been thrust northward an unknown amount over the northern limb. Current estimates of the original diameter of the transient crater are of the order of $100-200 \mathrm{~km}$, far larger than the present $30 \times 60 \mathrm{~km}$ surface outline of the basin.

Grieve (1994) showed that the newly recognized very large size of the Sudbury structure was consistent with all of the Sudbury Igneous Complex being an impact melt. Part of his argument was that Sudbury lies on the extension of the trend of numerous terrestrial impact craters in a plot of volume of impact melt against crater transient diameter. Faggart et al. (1985) had been the first to suggest on the basis of $\mathrm{Nd}$ isotope data that the Complex was entirely due to impact melting. Subsequent trace element and isotopic studies (Naldrett et al., 1986; Lightfoot et al., 1997a, 1997b) had shown that either their suggestion was correct, or that a mantle-derived magma had been contaminated by a very large proportion of impact melt or impact-heated country rock. The question as to whether the Sudbury Igneous Complex has incorporated any primitive, mantle-derived magma at all is still being argued. However, there is a growing body of isotopic evidence that the complex is an impact melt that incorporated $\mathrm{Ni}-, \mathrm{Cu}-$, and PGE-bearing mafic and/or ultramafic rocks that were already present in the target area (Keays and Lightfoot, 1999; Cohen et al., 2000).

The most recent major contribution to our understanding of Sudbury comes from the use of a modified version of computer code developed at Los Alamos (Amsden et al., 1980) to simulate the behavior and temperature of target rocks during a cratering event. Ivanov and Deutsch (1999) applied this to Sudbury and then used heat flow equations to estimate temperature variations in the resulting impact melt. Their plot of temperature in degrees Kelvin versus time for two hypothetical melt sheets is shown in Figure 9. The thinner lines represent a sheet with the present $2.5 \mathrm{~km}$ thickness of the Sudbury Igneous Complex, and the thicker lines a sheet $4 \mathrm{~km}$ thick. Blue lines are temperatures at the contact, red lines at the hottest point in the interior. Their calculations indicate that the maximum temperature within a $2.5-\mathrm{km}$-thick impact melt sheet would be about 2000 ${ }^{\circ} \mathrm{K}$ at the time of impact and that the temperature would remain above $1450{ }^{\circ} \mathrm{K}$, which is the approximate liquidus, for 250,000 years.

This extended period of superheat explains many features observed at Sudbury, including the extensive local contamination that is seen at the margins of the Sudbury Igneous Complex. It also explains the distribution of the sulfide ore. When one looks at other deposits of magmatic Ni-Cu sulfide, one finds that very commonly, the sulfides do not settle to the base of the overlying igneous body, but remain suspended as a cloud 
amongst cumulus silicate minerals. The Duluth Complex in Northern Minnesota is a case in point: very large zones of sparsely disseminated sulfide occur above the footwall along the northwestern margin of the intrusion. In contrast, deposits of massive sulfide are usually associated with feeder channels to lavas and intrusions, where hydrodynamic forces have caused the sulfides to concentrate (Naldrett, 1999). An example is the Voisey's Bay deposit on the coast of Labrador (see papers in Economic Geology, v. 95, no. 4). Here sulfides developed in a lower intrusion as a result of interaction with sulfide-bearing country rock. The sulfide-bearing magma flowed up a connecting dike into an upper intrusion. Sulfides become concentrated within swellings in the conduit and along the line of its entry into the upper intrusion. Ironically, Sudbury, which has so often served as the type model for exploration for magmatic sulfides, is the exception in which the sulfides have segregated very completely from the intrusion to concentrate within basal embayments. The high temperature and thus low viscosity of the superheated magma, coupled with the long time for which it remained superheated, account well for the unusually complete settling of the sulfides.

In summary, my story started 150 years ago with the discovery of a layered intrusion and associated Ni-Cu sulfides. Certain aspects bothered people for the next 110 years, including the huge amount of breccia and the very high proportion of felsic rock within the intrusion. Subsequent events are an object lesson on how progress is often made in our branch of science. Most of the basic facts had been known for 70 years as a result of the precise, hard work of generations of geologists. Other facts, such as shatter cones and shock deformation structures had undoubtedly been seen, but had not been appreciated for what they were. It took Robert Dietz's lateral mind to come up with a concept, for him to find time to look for critical evidence, and to propose a theory on the basis of this evidence. This was what was needed to bring many workers, with backgrounds that would never have drawn them to take an interest in a layered intrusion and its nickel deposits, to come to Sudbury and apply their special knowledge. As a result, a remarkable evolution in our geo- logical understanding has occurred over the past 40 years. We are not there yet. The Sudbury Igneous Complex is strongly differentiated whereas most melt sheets, including that in the $200 \mathrm{~km}$ diameter Chicxulub crater, are not. Sudbury also appears to lack the central uplift characteristic of most large impact craters. I suspect that the answer to these questions may come from a realization that the initial Sudbury crater was even larger than current estimates.

\section{ACKNOWLEDGMENTS}

I am most grateful to Larry Cochrane of NCO Ltd., John Machine, Bevan French, and Burkhardt Dressler for providing illustrative material for the actual talk, some of which is used here (as acknowledged). Support for my Sudbury research over the past 35 years has been provided by Canada's Natural Sciences and Engineering Research Council. Finally, I thank the Department of Geology, University of Toronto for providing me with a home base throughout this period.

\section{REFERENCES CITED}

Amsden, A.A., Ruppel, H.M., and Hirt, C.W., 1980, SALE: A simplified ALE computer program for fluid flow at all speeds: Los Alamos National Laboratory Report LA-8095, Los Alamos, New Mexico, 101 p.

Avermann, M.E., 1999, The green member of the Onaping Formation, the collapsed fireball layer of the Sudbury impact structure, Ontario, Canada, in Dressler, B.O., and Sharpton, V.L., eds., Large meteorite impacts and planetary evolution II: Boulder, Colorado, Geological Society of America Special Paper 339, p. 323-330.

Cohen, A.S., Burnham, O.M., Hawkesworth, C.J., and Lightfoot, P.C., 2000, Pre-emplacement Re-Os ages from ultramafic inclusions in the Sublayer of the Sudbury Igneous Complex, Ontario, Chemical Geology, v. 165, p. 37-46.

Dietz, R.S., 1959, Shatter cones in cryptoexplosion structures (meteorite impact): Journal of Geology, v. 67, p. 496.

Dietz, R.S., 1964, Sudbury structure as an astrobleme: Journal of Geology, v. 72, p. 412-434.

Dressler, B.O., 1984, The effects of the Sudbury event and the intrusion of the Sudbury Igneous Complex on the footwall of the Sudbury Structure, in Pye, E.G., et al., eds., The geology and ore deposits of the Sudbury Structure: Ontario Geological Survey Special Volume 1, p. 97-138.

Faggart, B.E., Basu, A.B., and M. Tatsumoto, M., 1985, Origin of the Sudbury Complex by meteorite impact: Neodymium isotopic evidence: Science, v. 230, p. 436-439.

Fedorowich, J.S., Rousell, D.H., and Peredery, W.V., 1999, Sudbury Breccia distribution and orientation in an embayment environment, in Dressler, B.O., and Sharpton, V.L., eds., Large meteorite impacts and planetary evolution II: Boulder, Colorado, Geological Society of America Special Paper 339, p. 305-315.

French, B.M., 1967, Sudbury structure, Ontario: Some petrographic evidence for an origin by meteorite impact: Science, v. 156, p. 1094-1098.

French, B.M., 1970, Possible relations between meteorite impact and igneous petrogenesis, as indicated by the Sudbury structure, Ontario, Canada: Bulletin Volcanique, v. 34, p. $466-517$.

Grieve, R.A.F., 1994, An impact model of the Sudbury Structure, in Lightfoot, P.C., and Naldrett, A.J., eds., Proceedings of the Sudbury-Noril'sk Symposium: Ontario
Geological Survey Special Volume 5, p. 119-132.

Hawley, J.E., 1962, The Sudbury ores: Their mineralogy and origin: Canadian Mineralogy, v. I, pt. 1, 207 p.

Horz, F., 1968, Statistical measurements of deformation structures and refractive indices in experimental shock-loaded quartz, in French, B.M., and Short, N.M., eds., Shock metamorphism of natural materials: Baltimore, Maryland, Mono Book Corporation, p. 243-253.

Ivanov, B.A., and Deutsch, A., 1999, Sudbury impact event: Cratering mechanics and thermal history, in Dressler, B.O., and Sharpton, V.L., eds., Large meteorite impacts and planetary evolution II: Boulder, Colorado, Geological Society of America Special Paper 339, p. 389-397.

Keays, R.R., and Lightfoot, P.C., 1999, The role of meteorite impact, source rocks, protores and mafic magmas in the genesis of the Sudbury Ni-Cu-PGE sulfide ore deposits, in Keays, R.R., et al., eds., Dynamic processes in magmatic ore deposits and their application in mineral exploration: Geological Association of Canada, Short Course Notes, v. 13, p. 329-366.

Lightfoot, P.C., Keays, R.R., Morrison, G.G., Bite, A., and Farrell, K.P., 1997a, Geochemical relationship in the Sudbury Igneous Complex: Origin of the main mass and offset dikes: Economic Geology, v. 92, p. 289-307.

Lightfoot, P.C., Keays, R.R., Morrison, G.G., Bite, A., and Farrell, K.P., 1997b, Geologic and geochemical relationships between the Contact Sublayer, inclusions and the main mass of the Sudbury Igneous Complex: A case study of the Whistle mine embayment: Economic Geology, v. 92, p. 647-673.

Masaiitis, V.L., Shafronowsky, G.I., Grieve, R.A.F., Langenhorst, F., Peredery, W.V., Therriault, A.M., Balmasov, E.L., and Fedorova, I.G., 1999, Impact diamonds in the suevitic breccias of the black member of the Onaping Formation, Sudbury Structure, Ontario, in Dressler, B.O., and Sharpton, V.L., eds., Large meteorite impacts and planetary evolution II: Boulder, Colorado, Geological Society of America Special Paper 339, p. 317-322.

Milkereit, B., White, D., Adam, E., Boerner, D., and Salisbury, M., 1994, Implications of the Lithoprobe seismic reflection transect for Sudbury geology, in Pye, E.G., et al., eds., The geology and ore deposits of the Sudbury Structure: Ontario Geological Survey Special Volume 1, p. 11-20.

Muller, W.F., and Defourneaux, M., 1968,

Deformationsstrukturen im Quarz als Indikator fur Stosswellen: Eine experimentelle Untersuchung an QuarzEinkristallen: Zeitschrift fur Geophysik, v. 34, p. 483.

Naldrett, A.J., 1999, World class Ni-Cu-PGE Deposits: Key factors in their genesis: Mineralium Deposita, v. 34, p. 227-240.

Naldrett, A.J., Rao, B.V., and Evensen, N.M., 1986, Contamination at Sudbury and its role in ore formation, in Gallagher, M.J., et al., eds., Metallogeny of basic and ultrabasic rocks: London, Institute of Mining \& Metallurgy, Special Publication, p. 75-92.

Peredery, W.V., 1972, Chemistry of fluid glasses and melt bodies in the Onaping Formation: Geological Association of Canada Special Paper 10, p. 49-59.

Von Engelhardt, W., Arndt, J., Stoffler, D., Muller, W.F., Jeziorkowski, H., and Gubser, R.A., 1967, Diaplektische Glaser in den Breccien des Ries von Nordlingen als Anzeichen fur Stosswellenmetamorphose: Contributions to Mineralogy and Petrology, v. 15, p. 93-102.

Von Engelhardt, W., Stoffler, D., and Schneider, W., 1969, Petrologische Untersuchungen in Ries: Geologica Bavaria, v. 61, p. 229-295.

Wandke, A., and Hoffman, R., 1924, A study of the Sudbury ore deposits: Economic Geology, v. 19, p. 169-204.

Wilshire, H.G.F., 1971, Pseudotachylites from the Vredefort ring, South Africa: Journal of Geology, v. 79, p. 195-206. 